Nebojša Janićijević

\title{
Contradictory Values in the Process of Organizational Change: a Case Study
}

DOI: 10.7595/management.fon.2017.0009

\begin{abstract}
Values have always been perceived as a guide for action at both individual and organizational levels. By showcasing an example of one Serbian company, the paper aims to present how employees and managers' collective values can be inconsistent and contradictory, as well as the causes and effects of such a state of company' system of values. The research was conducted by applying a case study method in a Serbian company comprising both qualitative and quantitative research techniques. The company was in the process of intensive organizational changes at the time of the research. The research has shown that it is possible for values of the employees and managers to be contradictory and that this contradiction is caused by radical changes both in the environment and in the organization itself. The research has also shown that this contradiction characterizes the Moving Phase in the process of organizational change, and that it is likely to disappear when company moves into the Refreezing Phase in the change process. The conclusions of this paper imply that the structure of collective values in organizations must be taken into account both in research and in practice of change management. Generalization of conclusions and implications is limited by the nature of the applied case study research method.
\end{abstract}

Keywords: values, organizational culture, transition, organizational change, Serbia

JEL classification: M10, M14

\section{Introduction}

Human behaviour is, both generally and in organizations, determined by extrinsic and intrinsic factors (Aronson, Wilson \& Akert, 2016; Robbins \& Judge, 2016). Rewards, systems and structures that govern the organization members' actions and decisions are prominent extrinsic factors. Motives and needs, knowledge and abilities, as well as cognitive components, such as assumptions, values, or norms, are prominent intrinsic factors. Among cognitive determinants of human behaviour in organizations, values are prominent as a prescriptive cognitive structure that "prescribes" peoples' actions, interactions and decisions. Values have always been perceived as a guide for action at both individual and organizational levels (Stackman, Pinder \& Connor, 2000). People almost always behave according to their values, so their actions, interactions, and decisions most often comply with their values (Fiske \& Taylor, 1991).

This is precisely the reason why causes, processes and effects of the value changes are a very important research topic if we tend to understand organizations and their changes. Changes of values, both individual and collective, shared by the people in organizations happen slowly and with difficulty, and most often in the face of dramatic changes in the environment or within organizations themselves (Tormos, Vauclair, \& Dobewall, 2017; Boniface, Mitchell \& Rashmi, 2012; Rafferty, Jimmieson \& Armenakis, 2013). The transition process, which Serbia has been in for several decades now, is an ideal context for changing the values of 
the Serbian companies' employees, with highly significant consequences on structure and functioning of the said companies. However, up until now there has not been much research that dealt with the changes in values of managers and employees in Serbian companies under the impact of transition and organizational transformation (Janicijevic, 2006). By using one company as an example, the aim of this paper is to investigate the process of changes in values and the state of contradiction between individual values in the course of this process.

\section{The theoretical framework}

Value is defined as "a part of common symbolic system, which serves as a criterion or standard for choosing between intrinsically available alternative orientations in given situation" (Parsons, 1951, p.39), or as "a conception, explicit or implicit, distinctive of an individual or characteristic of a group, which influences the selection from available modes, means and ends of action" (Kluckhohn, 1951, p. 395), or as "global beliefs (about desirable end-states or models of behaviour) that underlie attitudinal processes" (Connor, Becker, 1994, as cited in Stackman, Pinder \& Connor, 2000, p.188), and as "an enduring belief that a specific mode of conduct or end-state of existence is personally or socially preferable" to an opposite one (Rokeach, 1973, p. 136). All these definitions advocate that human behaviour is generally, as well as in organizations, guided by values and also that, when the values of an individual or a group are familiar to us, we can predict their behaviour as well.

Collective values (values shared by organizational members) are the core of organizational culture. Besides values, this construct also includes other layers of organizational members' mental schemes, such as assumptions, norms, attitudes, etc., but values are often underlined as the central element of organizational culture's content (Schein \& Schein, 2017; Janicijevic, 2013; Hofstede, Neuijen, Ohayiv \& Sanders, 1990). Unlike individual values, collective values as organizational culture element synchronously guide the behaviour of many organizational members, thus creating the effect of coordinated collective action, which is the foundation of the very organization. Collective values emerge in the process of organization members' social interactions while solving the organization's problems (Schein \& Schein, 2017). Social interaction process leads to social construction of reality, and thereof emerge the shared values of the members of social community (Berger \& Luckman, 1966).

Through its influence on the thoughts and behaviour of managers and employees, collective values contained in organizational culture influences different aspects of management and organization. Extensive empirical research has documented that organizational culture affects strategy (Klein, 2011; Yarbrough, Morgan, \& Vorhies, 2011), performance control (Deem, Barnes, Segal, \& Preziosi 2010), organizational structure (Ranson, Hinings, \& Greenwood, 1980), compensation systems (Chen, 2010), performance appraisal (Henri, 2006), organizational learning and knowledge management (Zheng, Yang, \& McLean, 2010; Alavi, Kayworth, \& Leidner, 2005), leadership (Giberson et al. 2009; Berson, Oreg, Dvir, 2008), job satisfaction (Lund 2003; Silverthorne, 2004) and organizational performance (Balthazard, Cooke \& Porter, 2006).

Values, both individual and collective, are difficult to change because they are subconscious categories; it takes a long time to create them and they become part of individual's identity, so changing them is always unpleasant (Schein \& Schein, 2017; Alvesson \& Sveningsson, 2016, Janicijevic, 2013). This does not mean that they are unchangeable and they are not changing at all. Organizational changes can also include changing of the organization members' system of values (Tormos, Vauclair \& Dobewall, 2017; Cameron \& Quinn, 2011). These are always deep, radical or second order changes (Bartunek, 1984). During such changes, the organization members change not only their way of working and behaving, but also their values, assumptions, norms, and attitudes. Most authors (Schein \& Schein, 2017; Alvesson \& Sveningsson, 2016; Janicijevic, 2013). agree that the process of changing values, follows Lewin's "Unfreezing, Moving, Refreezing" model (Lewin, 1951) and that the process of changing the organization members' cognitive structures (often described as their personal transition) unfolds so that the existing values weaken while new values (which are independent or even opposite to the existing ones) simultaneously appear in the unfreezing stage. Thus, the organization members transit into the moving stage in some kind of a schizophrenic state, that is, they simultaneously appreciate the old and the new values, which are unrelated or even contradictory (Hinings \& Greenwood, 1988). This state is called cognitive dissonance and it is very unpleasant (Fiske \& Taylor, 1991). Therefore, people tend to leave that state as soon as possible by changing 
their values in order to restate their compatibility. This occurs because the organization members cannot abandon the old values until they have previously built and accepted new ones. If the new values prevail, the organization members experience a personal transition during which they abandon their old values. Naturally, the old values may also prevail, and in this case not only that there is no change in the organization members' values, but there is also no change in their behaviour. It may also happen that the organization members stay in a schizophrenic state longer, that is, with the old and the new mutually inconsistent values. In the refreezing stage, the organization members reaffirm their set of mutually consistent values.

Changes of the organization members' values are so deep and hard that it is difficult to imagine how they would unfold without deep and radical changes in the environment and/or the organization itself. The transition process in the Eastern Europe economies and societies is a par excellence discontinuous change, which may have initiated a change in the values of the employees and managers in these countries' companies (Myant \& Drahokoupil, 2011; Lukášová, Franková \& Surynek, 2006; Janicijevic, 2006). Abandoning of the centrally planned economy founded on state ownership and building of a market economy founded on private ownership have initiated radical changes in how companies within these economies conduct their business. These changes are most often initialized by privatization of the stateowned companies, building of market economy institutions, and adopting managerial technology characteristic of company management in market economy. Such changes in companies' environment, and within themselves, also provoke changes in the organization members' individual and collective values. In the course of these changes, according to Lewin's model (1951), the organization members hold contradictory values.

\section{Methodology of the research}

The research of changes in values was conducted by method of case study analysis in Serbian company Sintelon. At the time of the research, the Sintelon company was one of the most successful companies for textile and vinyl flooring production in Serbia with 2550 employees. The company was founded and functioned for a long time as a state-owned enterprise, as did almost all companies in Serbia which was a republic in socialist Yugoslavia. However, in the 1990s Sintelon experienced transformational changes initiated by its privatization, as well as by the transition of Serbia from centrally planned to market economy model. Besides privatization between 1998 and 2000, many other changes occurred in the company owing to its leaders who wanted to adopt contemporary company management methods, which were the standard in developed market economies. Thus, they developed or improved strategic and business planning systems, human resources management systems (planning, performance appraisal, compensation system) and also SAP - integrated information system. These changes had also initiated the changes in the collective values of the Sintelon's employees and managers.

The research of values in Sintelon was performed through a hybrid approach comprising qualitative and quantitative research methods (Janicijevic, 2011) in three phases. First, qualitative data were gathered primarily through interviews and observations. In this phase, 28 employees and managers from different organizational units and of different ages, education levels and sex were interviewed. The purpose of the interviews was to identify the issues important to the organization members, since their shared values had been created around the said issues. By grouping the interconnected issues, we have identified 7 values whose formulation has been devised based on issues through which they have been identified. Also, the analysis of cultural symbols and their meanings was performed, including material (facilities, working areas, logo, clothing), semantic (myths, legends, anecdotes) and behavioural symbols (rituals and ceremonies). Based on these results, a tailor-made questionnaire was created in the second phase of the research, by devoting one question to each identified issue. It contained 35 questions (with 5 questions dedicated to each of the 7 values) with five-level Likert scale responses and was distributed in all Sintelon units to 250 employees and manages of all qualification and hierarchical levels and all age-groups according to their percentage in the total number of employees. The questionnaires were filled-in anonymously at the company premises. The strength of each value was determined according to the degree of the respondents' agreeing with the attitudes towards the issues that reflect the value concerned. Correlation was used to determine relations between values. In the final phase, the results of qualitative and quantitative research were synthesized, and conclusions were drawn about the Sintelon employees' shared values and interrelations between them. 


\section{Results and Discussion}

The research into Sintelon's corporate culture has shown that it contains seven values as follows:

- Flexibility. Changes are good, so Sintelon should be open to changes and also have the ability to adopt and conduct them.

- Development. Development and growth are the primary condition for survival of the company, so Sintelon must continuously grow, develop and adopt new technologies, and the employees must gain new skills and knowledge.

- World business standards. Sintelon should operate according to the rules and methods followed by all successful world companies in developed market economies.

- Results. Results are the only thing that counts, so in Sintelon everyone is valued solely based on the results they achieve.

- Employees' needs. Sintelon is responsible for its employees and must ensure that all their needs are satisfied.

- Consumers' needs. Consumers' needs should be the focus of all Sintelon's processes and activities.

- Privatization. Sintelon should be organized and managed like all joint-stock companies in developed market economies.

The employees accept the identified values to a different degree which manifests in the average grade on the 1 to 5 scale. The values of development, results and employees' needs are most accepted, and the value of privatization is the least accepted.

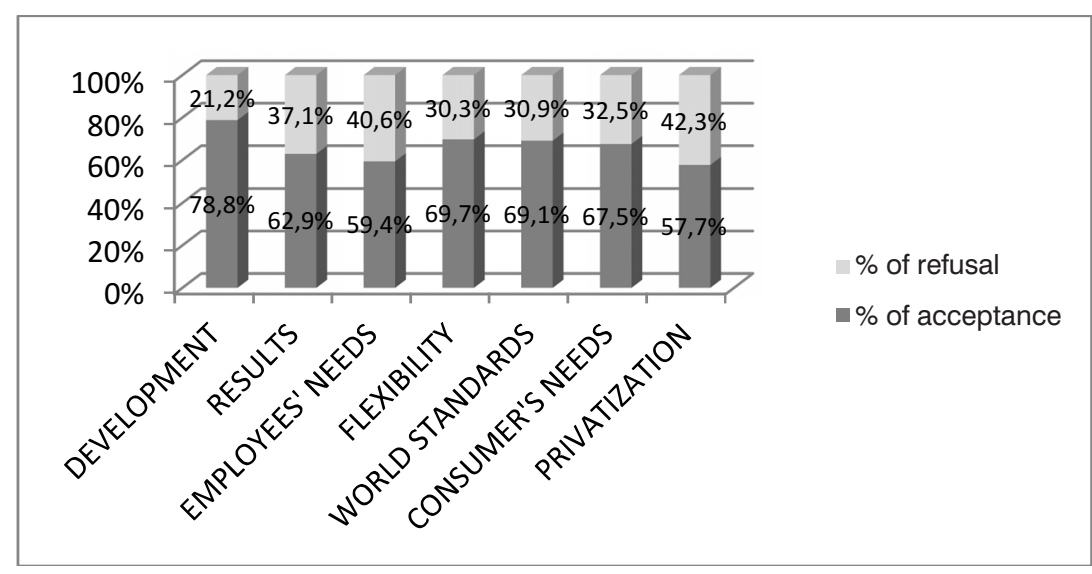

Figure 1. Acceptance of shared values in Sintelon

Source: The author's research

Most values shared by Sintelon's employees and managers are the results of two company's leaders: the company president and the CEO. From the mid 1990s, and especially from the beginning of the company's privatization process, the two leaders strived to establish new values in Sintelon's culture. They have succeeded because almost all the values are compatible with their vision. Their goal was to transform Sintelon from a typical socialist state-owned company into a contemporarily managed private company which would operate in a free market. The acceptance degree of the values these leaders imposed is very high, and this proves that they have been successful in creating the company culture as a set of collective values. However, the value of employees' needs is inherited from the past and it shows that Sintelon and its culture are still in the process of change, that is, the moving phase.

When analyzing the structure of Sintelon's collective values, we may notice one group of mutually consistent and related values, as well as two or three values that are excluded from the set. Values of flexibility, development, results and world standards highly positively correlate with each other. This shows that the employees perceive these 4 values as mutually compatible rules for the company's organizing and operating. Sintelon's least accepted value of privatization is positively correlated only with the value of development which shows that the employees perceive privatization as a condition and mechanism for the company's development. The value of consumers' needs is not positively correlated with any of the five 
previously mentioned values. Although it might be assumed that this value is established as the result of the company president's and CEO's leadership, still it appears that they were not very successful in that domain. The fact that it does not correlate with the values of development or world business standards shows that the Sintelon's employees have not completely accepted the management's marketing orientation.

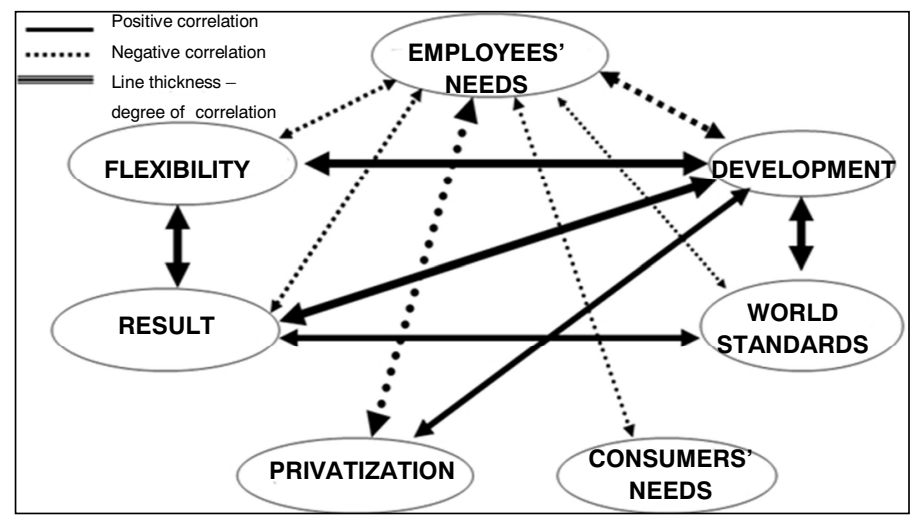

Figure 2: Correlation between shared values in Sintelon

Source: The author's research

The most interesting result of the interrelations between shared values of Sintelon's employees and managers relates to the value of employees' needs and its relation to other values. It is negatively correlated to all other Sintelon's shared values. This negative correlation is the strongest with the values of privatization and development. It seems that the employees believe that privatization will jeopardize the company's caring for them, which may be expected, but also that this caring would weaken in the course of company's development, which is much harder to explain. This value negatively correlates even with the consumers' needs, although it cannot be rationally explained how this value would jeopardize the value of caring for the employees. Obviously, the value of caring for the employees is inherited from the previous socialist period, when Sintelon was state owned and when its social responsibility for the employees was highly prominent and ideologically supported by the ruling communist party. Another very important source of this value is Serbian national culture. It is characterized, according to Hofstede, by high collectivism and high power distance (Hofstede, 2001). Collectivism implies the belief that a community (family, company, state) is bound to care for the wellbeing of its members, who in return offer their full loyalty (Janicijevic, 2013; Hofstede, 2001). The Sintelon's employees just transferred this belief to the company level, as most employees in Serbian companies did at the time. Power distance implies high authoritarianism and the belief that unequal distribution of power in society or organization is necessary and justified. High power distance combined with collectivism implies that the responsibility for one's own destiny is shifted from the hands of the community members and put into the hands of the authority that leads the collective (political or business leaders). This creates additional inertia in the community members, because they do not think that they should do something about their own wellbeing, but expect someone else to take care of them while in return they would provide obedience and loyalty. The value of employees' needs in Sintelon contains both of these components. Obviously, the value of employees' needs is in complete opposition to the values of development, world standards, results, and privatization. Sintelon leaders could not or would not remove this value, so it stayed in the collective values set. The case study has shown that Sintelon leaders strived to not question the said value and to show they believe in it so they would not provoke the employees' resistance and so all other values they had established would be accepted. The consequence is the contradiction within the company's shared values set. On the one hand, there is the value of employees' needs, while on the other hand there are all other values, and especially the 4 core ones. This situation is simply the consequence of the company's transformation and its comprehensive changes, including the cultural values changes. During the research period, Sintelon was in the moving phase, and all its employees had contradictory values. It is highly likely that the employees' needs value weakened more with Sintelon's further transformation, and then disappeared from the Sintelon's employees' collective values set. Namely, if we assume that the contradiction between values is the result of the moving phase in the transformation process, then we may conclude that the transition of the company into the refreezing phase will cause consolidation of collective values, eliminate contradictions between them and bring consistency into the company's collective values system. 


\section{Conclusion, implications and limitations}

Values as a "conception of desirable" guide all human activity, since they determine what is right and how to achieve it. Organizations are, as social entities, characterized by collective values, that is, the values shared by a majority of organization members. Collective, or shared, values of the organization members shape the organization's structure and functioning. Radical changes, such as privatization and transition, in the environment or in the organization itself may lead to significant changes in values of the managers and employees. When an organization is changing, it undergoes three common phases: Unfreezing, Moving, and Refreezing. In the Moving Phase of organizational changes, new values that are contradictory to the existing ones might occur. In this case, during the moving phase of organizational transformation, the organization will contain contradictory values and the organization members will enter the state of cognitive dissonance. This means that for a certain period of time during the moving phase the organization members will simultaneously hold mutually contradictory values. However, when the moving phase ends and when the organization enters the Refreezing Phase, these contradictions between values will probably disappear and the values that are contradictory to most other values will weaken and vanish.

The implications of this paper are both theoretical and practical. The theoretical implication of this paper is the need to include cognitive structure changes when researching organizational changes. Another implication of the paper is the need to investigate in more detail the causes, characteristics and effects of contradictions between values as a very interesting state of the employees' cognitive structures. The key practical implication of the paper is the need for the management of a company in the process of transition to actively work on managing the employees' values in order to facilitate the process of changes.

The paper has certain limitations that should certainly be mentioned. They emerge, above all, from the case study research method applied in it which prevents generalization and thus diminishes the value of the conclusions in the paper. Also, the process of value changes has been researched in one limited time period, while a more adequate method would be a longitudinal research. Finally, research into values would be far more reliable if it were accompanied by research into practices that emerge from values.

\section{Acknowledgements}

This research study has been supported by the Republic of Serbia's Ministry of Education, Science and Technological Development, Program of Basic Research 2011-2014 project ON179062, "Contemporary Management and Marketing Methods in Improving Competitiveness of Companies in Serbia in the Process of its Integration in European Union".

\section{REFERENCES}

[1] Alavi, M., Kayworth, T.R., \& Leidner, D.E. (2005). An empirical examination of the influence of organizational culture on knowledge management practices. Journal of Management Information Systems, 22(3), 191-224. DOI: 10.2753/MIS0742-1222220307

[2] Alvesson, M. \& Sveningsson, S. (2016). Changing organizational culture: Cultural change work in progres. New York, NY: Routledge.

[3] Aronson, E., Wilson, T. \& Akert, R. (2016) Social Psychology 9th ed. New York: Pearson.

[4] Balthazard P., Cooke R.E., \& Porter R.A. (2006). Dysfunctional culture, dysfunctional organization: capturing the behavioural norms that form organizational culture and drive performance. Journal of Managerial Psychology, 21(8), 709-732. DOI: 10.1108/02683940610713253

[5] Bartunek, J. M. (1984). Changing interpretive schemes and organizational restructuring: An example of a religious order. Administrative Science Quarterly, 29 (3), 355-372. DOI: 10.2307/2393029

[6] Berger, P. L. \& Luckmann, T. (1966). The Social construction of reality: A treatise in the sociology of knowledge. Harmondsworth, MA: Penguin.

[7] Berson, Y., Oreg, S., \& Dvir, T. (2008). CEO values, organizational culture and firm outcomes. Journal of Organizational Behaviour, 29(5), 615-633. DOI: 10.1002/job.499

[8] Boniface M, Mitchell N. \& Rashmi M. (2012). Three Alternatives to Organizational Value Change and Formation. The Journal of Applied Behavioral Science, 48(3), 380-409.

DOI: $10.1177 / 0021886311428435$ 
[9] Cameron, K. \& Quinn, R. (2011). Diagnosing and changing organizational culture based on competing values framework. San Francisco, CA: Jossey Bass.

[10] Chen, A. (2010). Culture and compensation - unpicking the intricate relationship between reward and organizational culture. Thunderbird International Business Review, 52(3) 189-202. DOI: 10.1002/tie.20324

[11] Deem, J. M., Barnes, B., Segal, S. \& Preziosi R. (2010). The relationship of organizational culture to Balanced scorecard effectiveness. SAM Advanced Management Journal, 75(4) 31-40.

[12] Fiske, S. \&Taylor, S.E. (1991). Social Cognition. New York, NY: Addison-Wesley

[13] Henri, J.F. (2006). Organizational culture and performance measurement systems. Accounting, Organizations and Society, 31(1), 77-103. DOI: 10.1016/j.aos.2004.10.003

[14] Giberson, T.R., Resick, C.J., Dickson, M.W., Mitchelson, J.K., Randall, K.R., \& Clark M.A. (2009). Leadership and organizational culture: Linking CEO characteristics to cultural values. Journal of Business Psychology, 24(2), 123-137. DOI: 10.1007/s10869-009-9109-1

[15] Hofstede, G. (2001). Culture's consequences. 2nd ed. Thousand Oaks, CA: Sage.

[16] Hofstede, G., Neuijen B., Ohayiv D. D. \& Sanders G. (1990). Measuring organizational culture: a qualitative and quantitative study across twenty cases. Administrative Science Quarterly, 35(2), 286-316. DOI: $10.2307 / 2393392$

[17] Janicijevic, N. (2013). Organizaciona kultura I menadzment. Beograd: Ekonomski fakultet.

[18] Janicijevic, N. (2011). Methodological approaches in the research of organizational culture. Economic Annals, LVI (189), 69 - 100. DOI: 10.2298/EKA1189069J

[19] Janicijevic, N. (2006). Impact of privatization on managers' work related values. In B. Cerovic (ed). (2006). Privatization in Serbia: Evidence and analysis (265-287). Belegrade: Faculty of Economics.

[20] Klein, A. (2011). Corporate culture: Its value as a resource for competitive advantage. Journal of Business Strategy, 32 (2), 21-28. DOI: 10.1108/02756661111109743

[21] Kluckhohn, C. K. (1951). Values and value orientations in the theory of action. In T. Parsons and E. A. Shils (Eds.), Toward a general theory of action (pp. 388-433). Cambridge, MA: Harvard University Press

[22] Lund, D. B. (2003). Organizational culture and job satisfaction. Journal of Business \& Industrial Marketing, 18(3), 219-236. DOI: 10.1108/0885862031047313

[23] Lewin, K. (1951). Field theory in social science. New York, NY: Harp $\neg$ er \& Row.

[24] Lukášová, R., Franková, E. \& Surynek, A. (2006). Organizational culture of Czech manufacturing companies: An empirical typology. Journal of Eastern European Management Studies, 11(4), p. 349 - 371

[25] Myant, M., \& Drahokoupil, J. (2011). Transition Economies: Political Economy in Russia, Eastern Europe, and Central Asia. Wiley.

[26] Parsons, T. (1951). The Social system. New York, NY: Free Press.

[27] Rafferty, A. E., Jimmieson, N. L., \& Armenakis, A. A. (2013). Change readiness: A multilevel review. Journal of Management, 39(1), 110-135. DOI: 10.1177/0149206312457417

[28] Ranson, S., Hinings B. \& Greenwood R. (1980). The structuring of organizational structures. Administrative Science Quarterly, 25(1), 1-17. DOI: 10.2307/2392223

[29] Robins, S., Judge, T. (2016). Organizational behavior. Upple Saddle River, NJ: Pearson.

[30] Rokeach, M. (1973). The Nature of human values. New York, NY: Free Press.

[31] Schein, E. \& Schein, P. (2017). Organizational culture and leadership. 5th ed. Hoboken, NJ: Jogn Willey \& Sons

[32] Stackman, R., Pinder, C. \& Connor P. (2000). Values lost. In N. M. Ashkanasy, C. P. M Wilderom \& M. F. Peterson, (Eds.). 2000. Handbook of organizational culture \& climate (pp. 37-54). Thousand Oaks: Sage.

[33] Tormos, R., Vauclair, C. \& Dobewall, H. (2017). Does Contextual Change Affect Basic Human Values? A Dynamic Comparative Multilevel Analysis Across 32 European Countries. Journal of Cross-Cultural Psychology, 48(4), 490-510. DOI: 10.1177/0022022117692675

[34] Yarbrough, L., Morgan, N. A., \& Vorhies, D. W. (2011). The impact of product market strategyorganizational culture fit on business performance. Journal of the Academy of Marketing Science, 39(4), 555-573. DOI: 10.1007/s11747-010-0238-x

[35] Zheng, W., Yang, B., \& McLean, G. N. (2010). Linking organizational culture, structure, strategy, and organizational effectiveness: Mediating role of knowledge management. Journal of Business research, 63(7), 763-771. DOI: 10.1016/j.jbusres.2009.06.005 


\section{$1 / 1 / 1 / 1 / 1 / 1 / 1 / 1 / 1 / 1 / 1 / 1 / 1 / 1 / 1 /$ abouthentulor}

Nebojša Janićijević University of Belgrade, Faculty of Economics, Serbia jnebojsa@eunet.rs

Nebojša Janićijević is a full professor at the Faculty of Economics, University of Belgrade, where he teaches courses in the field of organization, human resource management, and change management to students at undergraduate, graduate and doctoral studies. So far, as an author and co-author he has published several books, and a number of articles in foreign and domestic academic journals. He has been at three study stays at the U.S. universities as a receiver of Fulbright Program fellowships.

Nebojša Janićijević is a consultant for leading domestic companies in the field of organizational restructuring and human resources management.

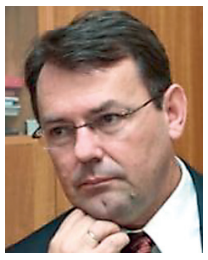

